\title{
THE VALUE OF FAMILY IN PROVERBS AND SAYINGS OF FOLKS LIVING IN THE TERRITORY OF THE EU
}

\author{
Ekaterina Fliginskikh \\ Prof., Mari State University, RUSSIA, katenasmile@mail.ru
}

\begin{abstract}
Proverbs always played a very important role in the life of folks as they accumulate the experience of previous generations and show the attitude to different issues. They cover all spheres of life, including private relations. The article analyses the most wide-spread proverbs and sayings of the folks living in the European countries that are devoted to the issues of love and family (239 units). It presents differences and similarities in the linguistic world view of different ethnic groups. The groups of proverbs under study are Love, Marriage, Husband \& Wife, Parents \& Children, and Home. The statistical analysis has shown that the biggest number of proverbs is devoted to love making it the most discussed issue (108 units). Among the countries where the topic of love and family is one of the most important there are Spain, Germany, France, Italy, and Romania (more than 20 units).

In the research to select the material for the purpose of study the author used a continuous sampling method, registration and processing of the data received, observation, analysis of each group of proverbs, a comparative analysis of the proverbs, statistical method.

Proverbs of the group Love describes different type of love. Proverbs of the group Marriage give the characteristic of the types of marriages. Proverbs of the group Husband \& Wife consider the relations between spouses. Most of the proverbs are devoted to wives giving them different treatment. Proverbs of the group Parents \& Children describe relations between generations. Both parents and children may behave good or bad. Proverbs of the group Home are devoted to attitude to homes. Home is considered as the best and most important place for people.
\end{abstract}

Keywords: proverbs, European countries, love, family, linguistic world view

\section{INTRODUCTION}

The European Union presents a political and economic union of 27 member states located in Europe. It mostly includes the countries of the Northern, Western, Central, and Southern Europe. Peoples living in the territory of all these countries have been developing close together beside each other for centuries exchanging opinions, ideas, objects of arts, and views of the world. A lot of such cultural values and views reflected in folk wisdoms in the form of proverbs and sayings (Gieron-Czepczor, 2020, p. 59-77; Zollner, 1985, p. 93-105; Torka, 2019, p. 200-209).

Proverbs and sayings belong to the intangible cultural heritage. Now the EU is following a special EU Policy 
for cultural heritage ${ }^{1}$ and priorities for $2019-2024^{2}$ that are also relevant for policy making in the field of culture.

There 24 official languages in the EU spoken in the EU member countries, and a lot more that are spoken in the EU countries. Most of these languages belong to Indo-European language family, the Maltese language belongs to the Afro-Asiatic language family, and the Estonian, Finnish and Hungarian languages belong to the Uralic language family. The worldview of all the peoples is reflected in the language they use, which is called the linguistic worldview.

Proverbs and sayings are studies by many linguists from different points of view: semantics and syntax (Ferary, 2018, p. 453-455), lexicology (Reis \& Baptista, 2017, p. 232-244), lexicography (Miletic, 2017, p. 519-537), particles (Pajusalu \& Pajusalu, 2011, p. 77-90), subjects as parts of a sentence (Ivankovic, 2015, p. 129-139), prosodic characteristics (Hallin \& Sidtis, 2017, p. 68-89). Some linguists study the paremiological cores of different languages carrying out comparative studies (Grzybek, 1989, p. 162-179; Helomaa, 2014, p. 357-360; Jensen, 1999, p. 131-134; Kotova, 2019, p. 363-371; Nelyubova, Syomina \& Kazlauskiene, 2020, p. 969-990). Moreover, proverbs and sayings are studies by specialists in folklore studies (Lelli, 2008, p. 125-141) and even management (Pfajfar, Uhan, Fang \& Redek, 2016, p. 433-457).

The most important topic of all the times is family. Making a happy family in the end has always been a goal of all peoples. That is why the topic of family was embodies in the proverbs and saying of different languages. It is necessary to mention that special attention in the proverbs and sayings is given to women wives and daughters (Buja, 2018, p. 215-222; Granbom-Herranen, 2010, p. 95-110; Williams, 1984, p. 7888).

The article presents a brief comparative comprehensive review of proverbs and sayings devoted to the topic of family that characterize the culture of folks living in the territory of EU member countries.

\section{MATERIALS AND METHODS}

To make the research the author selected proverbs and sayings of peoples living in the territory of the EU member countries devoted to family. There are 239 units used for the study. All the units were divided into four semantic groups: Love; Marriage, Husband \& Wife; Parents \& Children; Home.

In the research the author used different methods. To select the material for the purpose of study the author used a continuous sampling method while looking through different description of people's traditions and through the lists of proverbs and sayings (Bardosi, 2017, p. 86-99; Puccini, 2008, p. 63-64). The data received were registered into one of the four groups, processed and observed. Each group of proverbs and sayings was analysed, comparing the image of the discussed objects. At the end the statistical analysis was made.

All materials were studied in the English language so all proverbs and saying are presented in the form of translation to the English language. To make the difference between examples from different languages and countries, the official country codes were used: Austria (AT), Belgium (BE), Bulgaria (BG), Croatia (HR), Republic of Cyprus (CY), Czech Republic (CZ), Denmark (DK), Estonia (EE), Finland (FI), France (FR), Germany (DE), Greece (EL), Hungary (HU), Ireland (IE), Italy (IT), Latvia (LV), Lithuania (LT), Luxembourg (LU), Malta (MT), Netherlands (NL), Poland (PL), Portugal (PT), Romania (RO), Slovakia (SK), Slovenia (SI), Spain (ES), Sweden (SE).

\section{RESULTS AND DISCUSSION}

\subsection{Proverbs and Sayings about Romantic Relations and Love}

Love is one of the strongest feelings people have. Love becomes a basis for future deeper relations. Love is reflected in proverbs and sayings which show different treatment of this feeling.

One the one hand, love is considered as something good. Love fills people with a sense of happiness and shows all their best traits of character: Where there is love, there is happiness (PL), Love makes all hearts gentle (RO), April weather, woman's love, rose-leaves, dice, and card-luck, change every moment (EL). Love changes everything around for the better: Love can turn a cottage into a golden palace (DE), Love makes labour light (NL). Love makes people equal: Love levels all inequalities (IT), Love understands all languages

\footnotetext{
${ }^{1}$ EU Policy for cultural heritage: https://ec.europa.eu/culture/cultural-heritage/eu-policy-for-cultural-heritage

2 Strategic framework for the EU's cultural policy: https://ec.europa.eu/culture/policies/strategic-framework-for-the-euscultural-policy
} 
(RO). Northern folks compare love with the sun which shows the importance of love and sweet feelings it causes: Being in love is like feeling the sun from both sides (FI), A life without love is like a year without summer (SE). Italians as representatives of a culture with a lot of art objects underline a creative power of love: Love is master of all arts (IT). The history shows a lot of examples when love made people to create great work of art.

One the other hand, love is considered as something bad. There are much more proverbs and sayings describing negative qualities of love. In general, love makes life of people difficult: Love is full of trouble (RO). Love makes people not to notice anything around them: Love is partner of blindness (CZ), Love is blind and thinks that others don't see either (DK), Love is blind to blemishes and faults (IE), Love is blind but sees afar (IT). As we can see, a lot of examples characterize a person in love as a blind one. Love makes people forget about wisdom, logic, and soundness: Love has produced some heroes but even more idiots (DK, SE). Love is assisted with bad feelings very often: Love is never without jealousy (RO), Anger increases love (IT). Love is tricky as one never knows real feelings and emotions of a partner: In love, there is always one who kisses and one who offers the cheek (FR). That is why it is possible to say that love is very dangerous as it seems very nice in its outer form, but it may leave people unhappy in the end: Love kills with golden arrows (ES), It is all one whether you die of sickness or of love (IE), Love is sweet captivity (CZ), Love begins with song and music and ends in a sea of tears (IE), Love is sweet in the beginning but sour in the ending (RO). Moreover, some peoples think love depends on money and wealth, which is shown by a lot of examples: When Want comes in at the door, Love flies out at the window (NL), Where poverty comes in, love goes out (SE), When poverty comes in at the door, love flies out of the window (RO), When misfortune comes in at the door, love flies out of the window (DE).

Such consideration of love helped us distinguish some main characteristics of love reflected in proverbs and sayings. First of all, it is necessary to note out-of-law status of love: Love rules without law (IT), Love knows no law (PT), Love rules without rules (IE). It means that love is always unpredictable and very changeable: Love is like the moon: now full, now dark (PL). On the one hand, one does not need anything special for love: Love is without reason (RO), Real love is when you don't have to tell each other (FR). On the other hand, love needs some investments. It was mentioned earlier that sometimes love requires wealth, but a lot of proverbs say that true love needs love and faith: Love demands faith, and faith firmness (IT), Love is paid with love (PT), If you want to buy love, love itself is the price you'll have to pay (IE). One Italian proverb tells about the unique character of the first love: There is no love like the first love (IT). However, some other proverbs underline the strength of old love: Old love does not rust (EE), Wrinkles are the gravestones of love (ES).

Due to its character, love is compared to different things. Most of comparisons have negative character. Love is named a decease as people may feel good or bad without any visible reason: Three diseases without shame: love, itch, and thirst (IE). Love is compared to things that are difficult to hide: Love, a cough, and smoke, are hard to hide (IE), Love, grief, and money cannot be kept secret (ES), Poverty and love are difficult to hide (SE), Love and poverty are hard to conceal (DK), Love, a cough, and smoke will not remain secret (FR), Love, fire, a cough, the itch, and gout are not to be concealed (DE). Love is compared to things that bring pain: In war, hunting, and love, for one pleasure a hundred pains (PT), The pleasure of love lasts but a moment, The pain of love lasts a lifetime (FR). Love is compared to money, and money wins in this case: Love can do much, money can do everything (ES), Love can do much, money can do all (DE). Love is compared to things that push people into a corner: Love is like war, begin when you like and leave off when you can (ES), Love is like a mousetrap: you go in when you want, but you don't get out when you like (ES). Love is compared to time, and they are equal: Love makes time pass away, and time makes love pass away (FR), Love kills time and time kills love (IT). However, there is one positive comparison that has two meanings: Love is like dew that falls on both nettles and lilies (SE). First, love makes everything and everybody equal; second, love supports life, it is like an infusive force.

We decided to separate proverbs containing the comparison of love with marriage into a separate group, as these phenomena have special relations. As it was mentioned before, love makes people blind, therefore, marriage may cure people from this decease: The only cure for love is marriage (IE), Love blinds your eyes, marriage opens them wide (FI), Love is blind, but marriage finds a cure (RO). Love and marriage are compared to plants. In this case we can see the sweetness of love and the bitterness of marriage: Love is a garden full of flowers and marriage is a field of stinging nettles (FI). Love and marriage are compared to the parts of the day. In all cases proverbs say that marriage kills love: Love is the dawn of marriage, and marriage is the sunset of love (FI), Marriage is the sunset of love (FR). However, there is one positive comparison which shows the opposite character of relations - marriage brings love: Love is often the fruit of marriage (FR). 
A number of proverbs and sayings give a piece of advice how to find a person for love or marriage and how to attract this person. There are especially a lot of examples in the German language. The first way to take woman's heart is through her children. In such a case, this refers to unmarried, divorced, or widowed women with children: Praise the child, and you make love to the mother (DK), He who wipes the child's nose, means to kiss the mother's cheek (DE). Women love their children very much, and if they see that a man is ready to take responsibility for their children, they will trust him. The second way is to do it through girl's mother, to blandish her. In this case, it refers to unmarried girls who live in the family of their relatives and depend on their opinion. Everybody knows that mothers can influence their daughter's opinion: I give a present to the mother but I think of the daughter (DE), If you want the daughter, you must kiss the mother (IT). The second way can also help to examine a girl closely and make a decision about future marriage. It will allow seeing what it is possible to expect in future: Have a close look at the mother and then marry her daughter (HU), Look first at the mother and then the daughter (RO). Other proverbs advice to look at the neighbour's household. People usually knew their neighbours and knew what they should expect from them: Buy your neighbour's ox, and woo your neighbour's daughter (DE), Wipe the nose of your neighbour's son, and marry him to your daughter (ES).

\subsection{Proverbs and Sayings about Marriage}

\subsubsection{Proverbs and Sayings about a Phenomenon of Marriage}

On the one hand, marriage is considered as something good. It is compared to heaven and brings love: Marriages are written in heaven (FR), Early marriage, long love (DE). Moreover, proverbs underline an important meaning of marriage, as it is connected with God: A marriage is a procession in which the cross goes first (AT).

On the other hand, a lot of proverbs describe negative features of marriage. Everything starts with wedding: The most dangerous food is wedding cake (AT), The wedding lasts for two or three days, but the trouble stays longer (CZ). Marriages are described as something not very pleasant: If marriage were a good thing, it wouldn't need witnesses (PT), Marriage is a sack full of ninety-nine snakes and one eel (ES), Marriage is a lick of honey and a barrel of bitter (MT). Marriages bring a lot of efforts, worries, and concerns: What is marriage, mother? Daughter, it is spinning, bearing children, and weeping (PT), Mother, what is marrying? Spinning, bearing children, and crying, daughter (ES), What is marriage, mother? "Child, it is spinning, having children, making money, and weeping (RO). Some examples are devoted to second marriages, especially, to marriages with widows: A second marriage is like a warmed-up meal (RO), He who marries a widow with three children, marries four thieves (DK), Who weds a widow with three children takes four thieves into his house (EE). Proverbs say that such marriages bring nothing good. Marriages are compared to deaths: Death and marriages make changes (IE). That is why marriages are very important - happiness in the life of people depends on them: If the bread in the oven is a failure you lose a week; if the harvest is a failure you lose a year; if marriage is a failure then you lose a life (EE), Better a good hanging than a bad marriage (DE), Anything is better than a bad marriage (IE), Marriage without lovemaking means sad consequences and sorrow (ML). Therefore, there are some pieces of advice that marriage is not necessary, and clever men do not marry: A young man should not marry yet, an old man not at all (GRE), Honest men marry soon, wise men never (IT).

General characteristics of marriage are connected with life after wedding. Proverbs and sayings say about the necessity to undertake efforts to have a happy coupledom: Marriages are all happy. It's having breakfast together that causes all the trouble (IE), There goes more to marriage than four bare legs in a bed (IT). Moreover, newlyweds' relatives shall not poach on their preserves: Married people need a home of their own (ES).

\subsubsection{Proverbs and Sayings about a Husband and a Wife}

The first group of proverbs and sayings in this part is devoted to relations of a husband and a wife. It is a general truth and tradition that a husband always had a leading role in the families that is why opposite situation cannot bring anything good: When the husband is a hen and the wife is a cock, the house is topsyturvy (MT). As for a wife, she was always a preserver of the hearth: Happy the marriage where the husband is the head and the wife the heart (EE). Another proverb shows the presentation of family relations in public: The wife carries the husband on her face; the husband carries the wife on his clothes (BG). Husband's clothes could show housewifely skills. Wife's face could show her satisfaction with her husband, on the one hand. On the other hand, it could show her husband's attitude toward her (if he was beating her).

Some proverbs show the importance of a woman for home and for a man. They say that only women can 
turn a house into a home: $A$ hundred men can make an encampment, but it requires a woman to make a home (NL), A house without a woman is like a fire without a bucket (BG). A woman can give care for a house and a man, and he shall appreciate it: $A$ man without a wife is like a field without a fence (FI), Your wife and your wheelbarrow are two things that you should never lend to anyone (LU). Women were estimated for their housewifely skills, that is why there are proverbs talking about girl's readiness to get married: Who can tie an oven brush, weave a sackcloth and turn over chitterlings is ready for marriage (EE).

On the other hand, there are a lot of proverbs describing women from a bad point of view. A lot of them show sad position a man appears in after wedding: The wife cries before the wedding, the husband after (LT, $\mathrm{LU})$, The woman cries before the wedding and the man after (PL). Estonian proverbs compare a wife with tobacco, and tobacco is given the leading role: It is better to be without a wife for a minute than without tobacco for an hour (EE). Some proverbs describe different social position of spouses: $A$ poor man who takes a rich wife has a ruler, not a wife (EL). And again we can find the skills women shall have to get married: A girl who cannot patch man's trousers in between the legs, must not marry at all, because what use does a man have of such a stupid wife (EE).

There are also proverbs about husbands. Some of them just describe husbands: $A$ man with a skinny wife is a deceitful man (EL). Others give advice to women: Marry a man older than you and not a younger man, who will tire of you (MT).

\subsection{Proverbs and Sayings about Parents and Children}

\subsubsection{Proverbs and Sayings about Parents}

Parents are very important in the life of every person that is why there are a lot of proverbs devoted to parents. Parents' goodness is very great and compared to magnificent objects of nature: Father's goodness is higher than the mountains. Mother's goodness is deeper than the sea (FI). However, parents' life may influence the life of their children in future, and not always it is good: Buy, buy, the children will pay the debts $(\mathrm{FI})$, The fathers have eaten sour grapes, and the children's teeth are set on edge (RO). These proverbs teach parents to think what they are doing during their life as their actions can affect their children's lives. Several proverbs underline the power of parents to bring up as many children, as they have: One father can support ten children; ten children cannot support one father (RO), A father maintains ten children better than ten children one father (DE), A mother can more easily feed seven children than seven children can feed one mother (FR). This proverbs show self-sacrificing attitude of parents and their dedication to their children.

Proverbs and saying describe a mother and a father differently, underlining their these or those traits. Fathers usually give the Name to their children, and mothers usually provide cosiness: From the father comes honour, from the mother comfort (NT). Mothers are described as more intimate to their children: What reaches the mother's heart will only reach the father's knees (ES, PL), while fathers are shown as more reserved: You cannot satisfy the whole world and your father (FR). That is why proverbs make a distinction between the notions of a 'father' and a 'dad': Any man can be a father, but it takes a special person to be a $\operatorname{dad}(\mathrm{IT})$.

A lot of proverbs talk about mother's love. It is presented as a strong, deep, fresh feeling: Mother's love is ever in its spring (FR), The greatest love is a mother's; then a dog's; then a sweetheart's (PL). For mothers their children are the best: There's only one pretty child in the world, and every mother has it (AT). Proverbs also indue mothers with such qualities as the pungency of wit, wisdom, and support. In this case mothers are compared to other people: An ounce of a mother's wit is worth a pound of schoolgirl's wit (DE), An ounce of mother is worth a pound of priests (ES), A good mother is worth a hundred teachers (IT). There are a number of proverbs that present the dependence of daughter's qualities on those of a mother. If the mother is given some good traits, the daughter is attributed with some bad ones, and vice versa: An indulgent mother makes a sluttish daughter (NT), A bustling mother makes a slothful daughter (PT), A busy women has a lazy daughter, a lazy women has a busy daughter $(\mathrm{HU})$, A tender-hearted mother makes a scabby daughter (FR).

\subsubsection{Proverbs and Sayings about Children}

Children very often resemble their parents both as they look and behave. So, the first group of proverbs and sayings is devoted to the resemblance of parents and children: Children have a hair of their father (BE), As the field, so the crops; as the father, so the sons (DE), Like father, like son; like mother like daughter (RO).

Such resemblance or difference may depend on how the child is brought up. There are a number of 
proverbs that give a piece of advice in this field: Children have more need of models than critics (FR). Children upbringing and rearing may declare and show itself outside the house and in their future: Children act in the village as they have learned at home (SE), Children tell in the highway what they hear by the fireside (PT), A man conducts himself abroad as he has been taught at home (DK), Children pick up words, as pigeons peas, And utter them again as God shall please (PT), The one who first shuts up in an argument is from a good family (SK).

A lot of proverbs and sayings show people's and parents' attitude to children. On the one hand, parents love and adore their children. Children are said to be the flowers of life. They bring happiness and joy. So the more children there are in the family, the happier the family is: There was already twenty in the family, so my grandmother had a baby (ES), How did you rear so many children? By being fondest of the little ones (PT). Children are the greatest treasures: Children are the riches of the poor (DK). They bring love at home: Bricks and mortar make a house, but the laughter of children makes a home (IE), Who has no children does not know what love is (IT), Children travel from the heart to the heart (SE). That is why parents forgive their children for some misbehaviour very often: No matter how misbehaved a child, the parents will accept (FI).

On the other hand, some proverbs and sayings present negative point of view about having children. They are said to bring sorrows, worries, and difficulties: Children are certain sorrow, but uncertain joy (DK). The more children there are, the more difficult and noisier it is: Children: one is one, two is fun, three is a houseful (PT), Children should be seen and not heard (PT), Many children, and little bread, is a painful pleasure $(\mathrm{DE}, \mathrm{IE})$. Moreover, all things are becoming more and more difficult as children are becoming bigger: Little children, little sorrows; big children, great sorrows (DK), Children raised, doubled work (PT), A baby is an angel whose wings decrease as his legs increase (FR), Children when they are little make parents fools, when they are great they make them mad (RO). Separate proverbs and saying are devoted to somebody's children (neighbour's or relatives') as they seem even worse than own children: Our neighbor's children are always the worst (DE), Don't tell secrets to the children of your relatives (IE).

There is a group of proverbs and sayings that name children prophet and talk about their protection by the God. In such examples children are compared to fools, sailors, and drunken men: Children and fools are prophets (FR), Children and fools speak the truth (DE), Children and fools tell the truth (ES), Children and drunken men speak the truth (DK), Heaven protects children, sailors, and drunken men (GR), God helps three sorts of people: fools, children and drunkards (FR).

A special group of proverbs and sayings is talking about daughters. They are considered to be both an apple of parents' eye and a handful of worries: Your son is your son until he marries, but your daughter is your daughter until you die (IE), Daughters may be seen but not heard (NT), A house full of daughters is a cellar full of sour beer (NT). Proverbs and sayings underline special relations of a father toward his daughters, which also may be different: he can feel lucky and happy: The lucky man has a daughter for his first-born (ES), or full of sorrows and worries: He who has daughters is always a shepherd (FR), Three daughters and their mother, four devils for the father (ES).

\subsection{Proverbs and Sayings about Home}

House refers to a building where someone lives. Home refers to a family, the atmosphere or a special place where someone feels most comfortable. There is a great number of proverbs and sayings emphasizing that home place a great role in the life of every person: He who wants to be happy must stay at home (EL), My home is my castle (PL), The clock ticks nowhere else the way it does at home (NL), Home is where he hangs his hat (ES). Home is compared to other places and always wins: East or west, home is best (NL), Away is good but at home is best (SE), It is good everywhere, but it is the best at home (HU), Foreign places are nice enough, but home is sweeter (FI). Home is especially essential if you can call it your own: Own home is worth gold $(\mathrm{Fl})$. That is why people living far from home may feel unhappy: He who is far from home, is near to harm (DK).

Another group of proverbs and sayings describes traits that can be cultivated at home. People can be judged by their homes: First look at home, then censure me (DE). Sweet home may develop and reveal the best traits of character and behaviour in people: Love begins at home (DE), Charity begins at home (RO), Justice begins at home (PT), The wolf commits no mischief at home (ES). That is why it is important to think of correct upbringing of children and giving them a good role model for the life.

Moreover, some proverbs and sayings give a piece of advice to solve the existing problems inside the family without presenting them in public: Dirty clothes one washes at home (PT), Dirty linen should be washed at home (RO), It is at home, not in public, that one washes his dirty linen (FR). 


\section{CONCLUSION}

In the concluding section we would like to present the statistical analysis of proverbs and sayings per groups and countries. The study includes 239 units. A statistical distribution of proverbs and sayings devoted to the issue of family per groups is presented in Fig. 1.

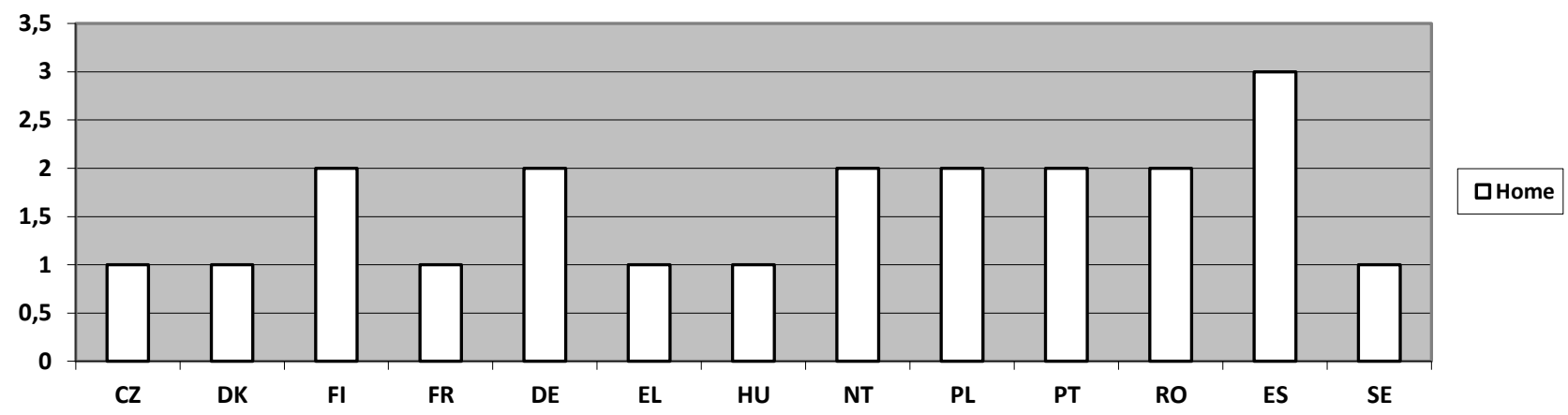

Fig. 1. Statistical distribution of proverbs and sayings per groups.

There are 108 selected and studied proverbs and saying about love (Fig. 2). The biggest quantity of examples belongs to the Italian, Romanian, German, Spanish, French, and Irish languages, which shows the great meaning of love for these folks. However, the most of the proverbs have negative meaning, as they describe a lot of difficulties connected with love.

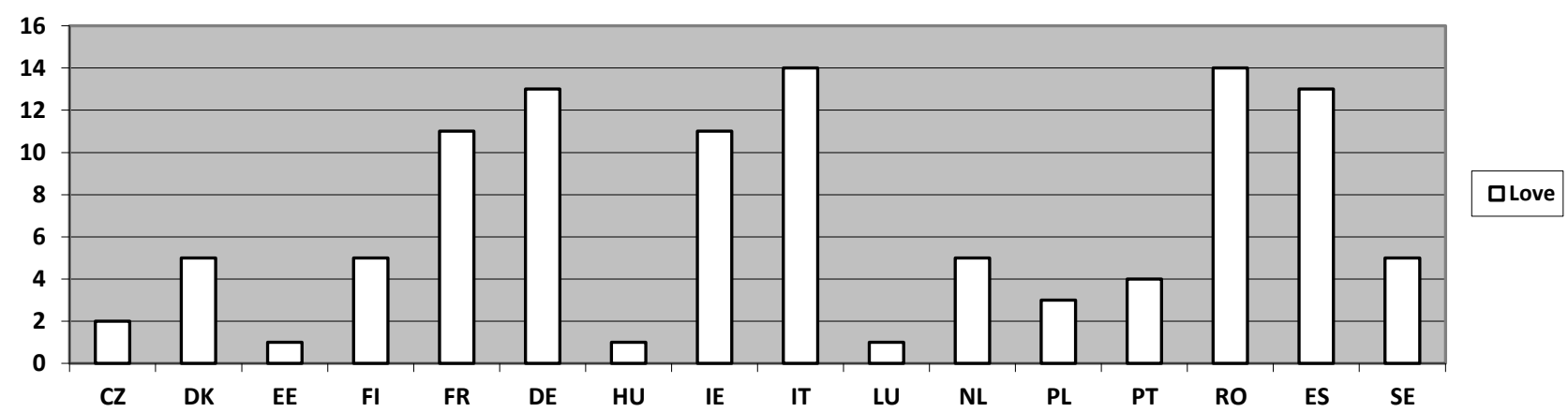

Fig. 2. Statistical distribution of proverbs and sayings devoted to love per countries.

There are 30 selected and studied proverbs and saying about marriage and 17 and relations of husbands and wives (Fig. 3). The biggest quantity of examples of proverbs about marriage belongs to the German, Spanish, Estonian, and Italian languages, which give both positive and negative opinion about it. The biggest quantity of examples of proverbs about relations of husbands and wives belongs to the Estonian language. Most of them describe bad treatment of a husband toward his wife.

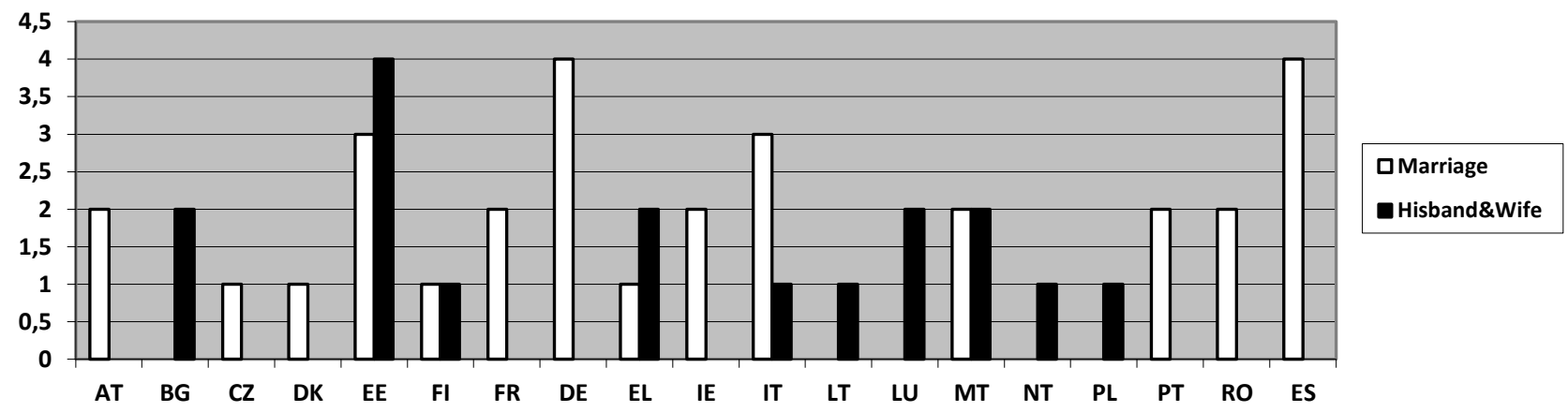

Fig. 3. Statistical distribution of proverbs and sayings devoted to marriage and spouses per countries.

There are 63 selected and studied proverbs and saying about relations of parents and children (Fig. 4). The 
biggest quantity of examples belong to the French, German, Portuguese and Spanish languages, which shows that these folks paid great attention to relations between generations. They describe both parents and children.

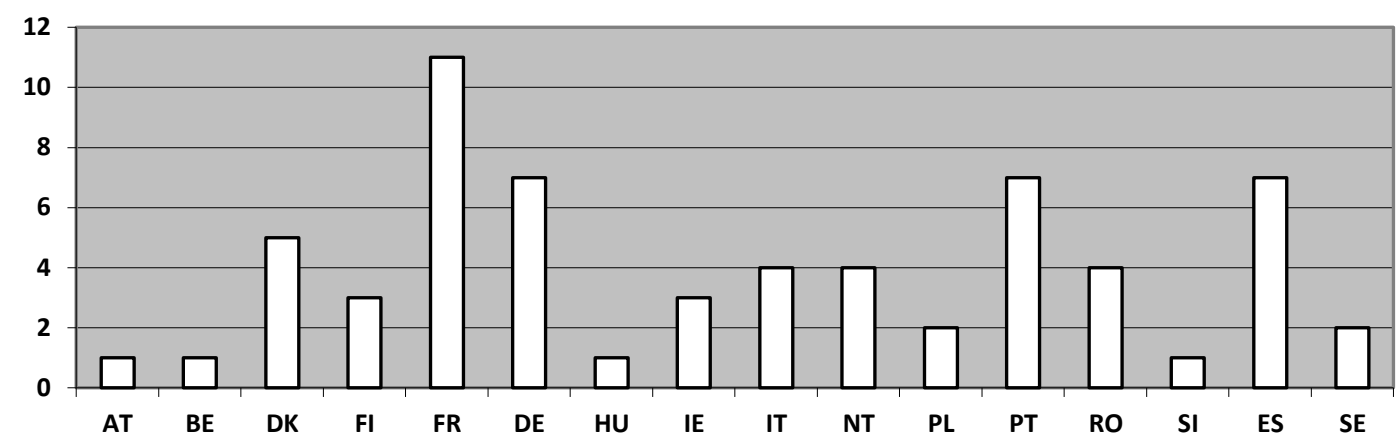

口Parents\&Children

Fig. 4. Statistical distribution of proverbs and sayings devoted to parents and children per countries.

There are 21 selected and studied proverbs and saying about home (Fig. 5). The biggest quantity of examples belongs to the Spanish language, which shows special meaning of home for this folk. All the proverbs have positive meaning describing home as the most important place.

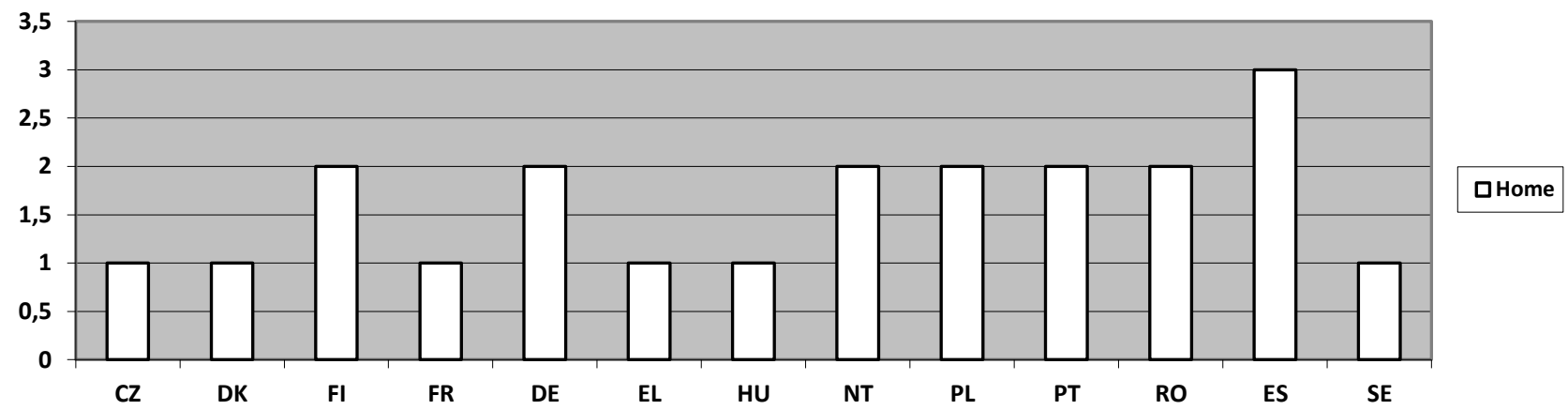

Fig. 5. Statistical distribution of proverbs and sayings devoted to home per countries.

To sum it up, it is necessary to say that it is important to study the culture and values of peoples and folks. They are often reflected in different paroemiae, such as proverbs and sayings. Such studies can help to understand the culture and the people better, to reveal their values. The comparative analysis allows defining similar features in the cultures presented in the same territory which justifies cultural exchange.

\section{REFERENCE LIST}

Bardosi, V. (2017). The New Etymological Dictionary of Hungarian Idioms and Proverbs. OPEN LINGUISTICS, 3 (1). http://dx.doi.org/10.1515/opli-2017-0005.

Buja, E. (2018). Women, Proverbs and Culture Diversity: A Comparative Study of Korean and Romanian Proverbs. REDEFINING COMMUNITY IN INTERCULTURAL CONTEXT, RCIC' 18, 7 (1).

Ferary, S. G. J. (2018). Proverbial diachrony: semantics, syntax and rhythm of French and Spanish proverbs. RILCE-REVISTA DE FILOLOGIA HISPANICA, 34 (2). http://dx.doi.org/10.15581/008.34.2.453-55.

Gieron-Czepczor, E. (2020). National cultural values in folk wisdom: The Indulgence (versus Restraint) Dimension in Polish proverbs. SKASE JOURNAL OF THEORETICAL LINGUISTICS, 17 (3).

Granbom-Herranen, L. (2010). Women's Place in Finnish Proverbs from Childhood. FOLKLOREELECTRONIC JOURNAL OF FOLKLORE (46).

Grzybek, P. (1989). Parallels between Latvian and German Proverbs. FABULA, 30 (3-4). 
Helomaa, S. (2014). Proverbs in Three Languages: German-French-Finnish. Eine Contrastive Studies. NEUPHILOLOGISCHE MITTEILUNGEN, 115 (3).

Hallin, A. E. \& Sidtis, D. V. (2017). A Closer Look at Formulaic Language: Prosodic Characteristics of Swedish Proverbs. APPLIED LINGUISTICS, 38 (1). http://dx.doi.org/10.1093/applin/amu078.

Ivankovic, I. M. (2015). Subjects in Croatian Proverbs. FLUMINENSIA, 27 (2).

Jensen, K. (1999). Proverbs. 700 Spanish proverbs with their Danish equivalents. REVUE ROMANE, 34 (1).

Kotova, M. Y. (2019). The Specifics of Bulgarian Proverbs in the Russian-Bulgarian-Czech-Slovak-English Paremiological Core. BULGARSKI EZIK I LITERATURA-BULGARIAN LANGUAGE AND LITERATURE, 61 (4).

Lelli, E. (2008). Ancient and modern proverbs. Folkloric comparison of proverb interpretations and Greek proverbial motives. QUADERNI URBINATI DI CULTURA CLASSICA, 89 (2).

Miletic, N. (2017). Problems of German lexicography proverbs. JEZIKOSLOVLJE, 18 (3).

Nelyubova, N. U., Syomina, P. S. \& Kazlauskiene, V. (2020). Gourmandise in the hierarchy of values: A case study of French and Belgian proverbs and sayings. VESTNIK ROSSIISKOGO UNIVERSITETA DRUZHBY NARODOV-SERIYA LINGVISTIKA-RUSSIAN JOURNAL OF LINGUISTICS, 24 (4). http://dx.doi.org/10.22363/2687-0088-2020-24-4-969-990.

Pajusalu, K. \& Pajusalu, R. (2011). From Conversation to Proverbs: Estonian ikka- and iks-Constructions. FOLKLORE-ELECTRONIC JOURNAL OF FOLKLORE (47).

Pfajfar, G., Uhan, M., Fang, T. \& Redek, T. (2016). Slovenian business culture - How proverbs shape dynamic leadership styles. JOURNAL OF EAST EUROPEAN MANAGEMENT STUDIES, 21 (4). http://dx.doi.org/10.5771/0949-6181-2016-4-433.

Puccini, D. (2008). Dictionary of proverbs. Italian proverbs organized by themes. LINGUA NOSTRA, 69 (12).

Reis, S. \& Baptista, J. (2017). Estimating Lexical Availability of European Portuguese Proverbs. COMPUTATIONAL AND CORPUS-BASED PHRASEOLOGY, EUROPHRAS 2017, 10596. http://dx.doi.org/10.1007/978-3-319-69805-2_17.

Torka, N. (2019). Honesty and genuine happiness Or why soft healers make stinking wounds (Dutch proverb). BRITISH JOURNAL OF GUIDANCE \& COUNSELLING, 47 (2). http://dx.doi.org/10.1080/03069885.2018.1453600

Uther, H. J. (2001). Lithuanian proverbs and proverbial expressions. FABULA, 42 (3-4).

Williams, F. (1984). Bachelors-Wives-And-Old-Maids-Children - A Look at the Men and Women in Irish Proverbs. ULSTER FOLKLIFE, 30.

Zollner, E. (1985). Austrian History through Anecdote, Proverb, Wit and Satire. MITTEILUNGEN DES INSTITUTS FUR OSTERREICHISCHE GESCHICHTSFORSCHUNG, 93 (1-2). http://dx.doi.org/10.7767/miog.1985.93.12.93.

ACKNOWLEDGEMENT. The present work is supported by the Education, Audiovisual and Culture Executive Agency (Jean Monnet Module No. 612020-EPP-1-2019-1-RU-EPPJMO-MODULE). 